\title{
HORMONE-INDUCED PEAR-APPLE HYBRIDS
}

\author{
R. D. BROCK \\ John Innes Horticultural Institution. Hertford, Herts. and Division of Plant Industry, \\ C.S.I.R.O., Canberra, Australia
}

Received $19 \cdot x \cdot 53$

\section{INTRODUCTION}

MaNY intergeneric hybrids are known, and in the Pomoideæ attempts to produce such hybrids by plant breeders have met with some success. A sexual hybrid between pear and apple was produced by Crane and Marks (1952) by using a growth regulating substance or hormone, $\beta$-naphthoxyacetic acid, on the pear ovary at the same time that it was pollinated with apple pollen.

Hormones have of recent years been used for two purposes. First there is the production of parthenocarpic fruit without pollination (Avery and Johnson, 1947; Zimmerman and Hitchcock, 1948). Osborne and Wain (195I) obtained parthenocarpic apples and pears in this way. Of the substances they tested only one, $\alpha$-(2-naphthoxy) propionic acid, was effective in producing mature fruit on pears and then only on a limited number of varieties. This substance was ineffective when applied to apples. A different substance, however, $\alpha$ phenoxypropionic acid, produced mature apples but again on only one of the three varieties tested. Thus the induction of parthenocarpic fruits in Pyrus seems to be a highly specific reaction.

Secondly, hormones have been used as an aid to crossing. Emsweller and Stuart (1948) found that for giving hybrids between species of Lilium, the most effective was naphthalene acetamide.

It is likely that the action of the hormones in assisting hybridisation is related to parthenocarpy. These studies were aimed at finding out the mode of action of $\beta$-naphthoxyacetic acid and also the reason for its rather limited effectiveness as an aid to crossing pears and apples.

\section{MATERIALS AND METHODS}

Crosses were attempted between various varieties of pears and apples. Immediately after pollination the ovary and base of the styles were brushed once with a 40 parts per million (p.p.m.) aqueous solution of $\beta$-naphthoxyacetic acid, care being taken to ensure that the hormone solution did not come in contact with the stigma or the pollen. Nine varieties of pears were used as female parents. Seven were diploid, one was triploid and one, Fertility Improved, was a periclinal polyploid chimera with diploid epidermis and tetraploid inner tissue (Marks, 1953).

Each pear variety was selfed and crossed with a diploid apple variety, Cox's Orange Pippin and with a tetraploid apple variety, $16-36$ AT. In addition self and cross pollinations without hormone treatment were made on Fertility. All of the pear varieties were self incompatible except the tetraploid Fertility Improved, so compatible pear-pear pollinations were made between Fertility and Conference. Conference flowers were also pollinated with cherry and plum pollen. 
Three diploid apple varieties were used as female parents. These were selfed and crossed with Fertility $(2 x)$ and Fertility Improved $(4 x)$ pears.

The fruit and seed set were recorded and the development of the embryo-sac, fertilisation and the early development of the embryo and endosperm were followed. The effect of hormone on rate of pollen tube growth was studied both in vitro and in vivo.

For embryological studies buds were fixed in Navashin fluid at daily intervals from meiosis until fourteen days after pollination. After embedding in wax, sections were cut $12 \mu, 16 \mu$ or $20 \mu$ thick and stained in crystal violet. Pollen tube growth of Cox apple and Fertility pear was measured after germination on cellophane floated on hormone in 15 per cent. sucrose (Darlington and La Cour, 1947). Pollen tube growth in pear styles, 1, 2, 4 and 8 days after pollination, was measured after fixation in acetic alcohol $(1: 3)$ and storage in 30 per cent. alcohol. Before examination they were softened in water for a few minutes, cut longitudinally, stained in 0.4 per cent. cotton blue in lacto-phenol and mounted in water, cut surface uppermost.

\section{FRUIT AND SEED SET}

Table I summarises the results of the crossing experiments and the following points are apparent :

(i) Parthenocarpy was induced in four of the pear varieties but in none of the apples.

(ii) Parthenocarpy requires hormone but does not require pollination.

(iii) Pear-apple hybrids were only formed in varieties capable of parthenocarpy.

(iv) The naturally parthenocarpic variety, Fertility, was the most favourable for hybridisation.

(v) Hormone-induced parthenocarpy and very slight seed formation occurred in self incompatible varieties. This seed setting may be due to the breakdown of the incompatibility system when the flowers are kept on the plant for longer than normal (East, I923), or to parthenocarpy allowing recovery of single-seeded fruits which would have otherwise been lost (Lewis, 1 948).

\section{EMBRYO-SAC DEVELOPMENT}

In all the varieties of pears the embryo-sac developed from an anatropoiss ovule with a thick nucellus. This differed slightly from the behaviour in apples described by Wanscher (1939) where a hypodermal cell of the nucellus developed into the megaspore mother cell. Meiosis occurred approximately six days before anthesis and resulted in a $\mathrm{T}$-shaped tetrad. The embryo-sac development was monosporic, the chalazal megaspore divided to give a two-celled embryo-sac four days before anthesis, a four-celled embryo-sac three days before anthesis, and an eight-celled embryo-sac one to two days before anthesis. At or shortly after anthesis the embryo-sac was organised into egg, synergids, polar nuclei and antipodals.

Fusion of the polar nuclei occurred between two and eight days after anthesis. The number of antipodal cells also varied. The 
maximum number observed was eighteen in one embryo-sac of the variety Conference. The modal number of antipodals varied from five to eight in the different varieties.

TABLE !

Results of crossing experiments with pears and apples using hormone treatment

\begin{tabular}{|c|c|c|c|c|c|c|}
\hline \& Parent & $\delta$ Parent & $\begin{array}{c}\text { Flowers } \\
\text { pollinated }\end{array}$ & $\begin{array}{c}\text { Mature } \\
\text { fruit }\end{array}$ & $\begin{array}{l}\text { Total } \\
\text { seeds }\end{array}$ & $\begin{array}{l}\text { Seeds } \\
\text { per } \\
\text { fruit }\end{array}$ & $\begin{array}{l}\text { Per cent. } \\
\text { germina- } \\
\text { tion }\end{array}$ \\
\hline \multicolumn{7}{|c|}{ A. Successful parthenocarpy or hybridisation } \\
\hline \multirow[t]{4}{*}{ Fertility $(2 x)$} & Compatible & 30 & 7 & 53 & $7 \cdot 6$ & $98 \cdot 1$ \\
\hline & $2 x$ Apple & 105 & 25 & 155 & $6 \cdot 2$ & $82 \cdot 6$ \\
\hline & $\begin{array}{l}\text { 4x Apple } \\
\text { Selfed }\end{array}$ & 105 & 32 & 157 & $\begin{array}{l}4 \cdot 9 \\
0 \cdot 07\end{array}$ & $\begin{array}{c}82 \cdot 2 \\
(100 \cdot 0)\end{array}$ \\
\hline & No pollen & $\begin{array}{l}35 \\
30\end{array}$ & 12 & o & ‥ & $\ldots$ \\
\hline \multirow[t]{4}{*}{ Conference $(2 x)$} & $2 x$ Apple & 30 & 3 & o & $\cdots$ & $\ldots$ \\
\hline & $\begin{array}{l}\text { 4x Apple } \\
\text { Selfed }\end{array}$ & $\begin{array}{l}30 \\
80\end{array}$ & $\begin{array}{r}4 \\
14\end{array}$ & $\begin{array}{l}3 \\
3\end{array}$ & $\begin{array}{l}0 \cdot 75 \\
0.22\end{array}$ & $\begin{array}{l}33 \cdot 3 \\
66 \cdot 7\end{array}$ \\
\hline & Cherry & 150 & 6 & o & $\ldots$ & $\cdots$ \\
\hline & Plum & $15^{\circ}$ & 10 & 0 & $\cdots$ & $\cdots$ \\
\hline \multirow[t]{2}{*}{ Doyenné du Comice $(2 x)$} & $2 x$ Apple & 30 & 2 & o & $\ldots$ & ... \\
\hline & $\begin{array}{l}4 x \text { Apple } \\
\text { Selfed }\end{array}$ & $\begin{array}{l}30 \\
3^{\circ}\end{array}$ & $\begin{array}{l}3 \\
0\end{array}$ & ${ }^{9}$ & $\begin{array}{r}3 \cdot 0 \\
\ldots\end{array}$ & $\begin{array}{r}100 \\
\ldots\end{array}$ \\
\hline \multirow[t]{2}{*}{ Fertility Improved $(4 x)$} & $2 x$ Apple & 30 & 1 & 0 & $\cdots$ & $\cdots$ \\
\hline & $\begin{array}{l}4 x \text { Apple } \\
\text { Selfed }\end{array}$ & $\begin{array}{l}30 \\
30\end{array}$ & $\begin{array}{r}0 \\
12\end{array}$ & $\dddot{74}$ & $\ddot{6 \cdot 2}$ & $\cdots$ \\
\hline \multicolumn{7}{|c|}{ B. Unsuccessful parthenocarpy and hybridisation } \\
\hline \multirow{4}{*}{$\begin{array}{l}\text { Pears } \\
\text { Clapp's Favourite }(2 x) \\
\text { Dr Jules Guyot }(2 x) \\
\text { Louise Bonne de Jersey } \\
\quad(2 x) \\
\text { Seckle }(2 x) \\
\text { Beurré d'Amanlis }(3 x)\end{array}$} & & & & & & \\
\hline & $2 x$ Apple & 30 & 0 & & & \\
\hline & $4 x$ Apple & 30 & o & & & \\
\hline & Selfed & $3^{0}$ & o & & & \\
\hline \multirow{3}{*}{$\begin{array}{l}\text { APpLes } \\
\text { Cox }(2 x) \text {. } \\
\text { * Lord Derby }(2 x) \\
\text { Merton Prolific }(2 x) \\
\text {. }\end{array}$} & & & & & & \\
\hline & $2 x$ Pear & 30 & o & & & \\
\hline & Selfed & $\begin{array}{l}30 \\
30\end{array}$ & $\begin{array}{l}0 \\
0\end{array}$ & & & \\
\hline
\end{tabular}

* One selfed fruit bearing one seed was obtained from Lord Derby.

Note.-Twenty-five flowers of Fertility $(2 x)$ with $2 x$ apple, $2 x$ pear, and no pollen gave no mature fruit.

Unfertilised ovules showed no sign of degeneration up to fourteen days after anthesis. There were no consistent differences in the form or timing of the embryo-sac development and it is therefore unlikely that variation in embryo-sac development is responsible for the difference in seed setting after hybridisation. 


\section{POLLEN TUBE GROWTH AND FERTILISATION}

Smith (1942) and Addicott (1943) both obtained stimulation of pollen germination and pollen tube growth by optimal concentrations of hormones and vitamins. Indolacetic acid stimulated at a concentration of ro p.p.m. High concentrations retarded both growth and germination. Addicott suggested that germination and growth are stimulated independently.

In the experiments with apple and pear pollen grown on cellophane the tube growth was stimulated at concentrations of $\beta$-naphthoxy acetic acid between I p.p.m. and 1o p.p.m. (fig. I). It is notable

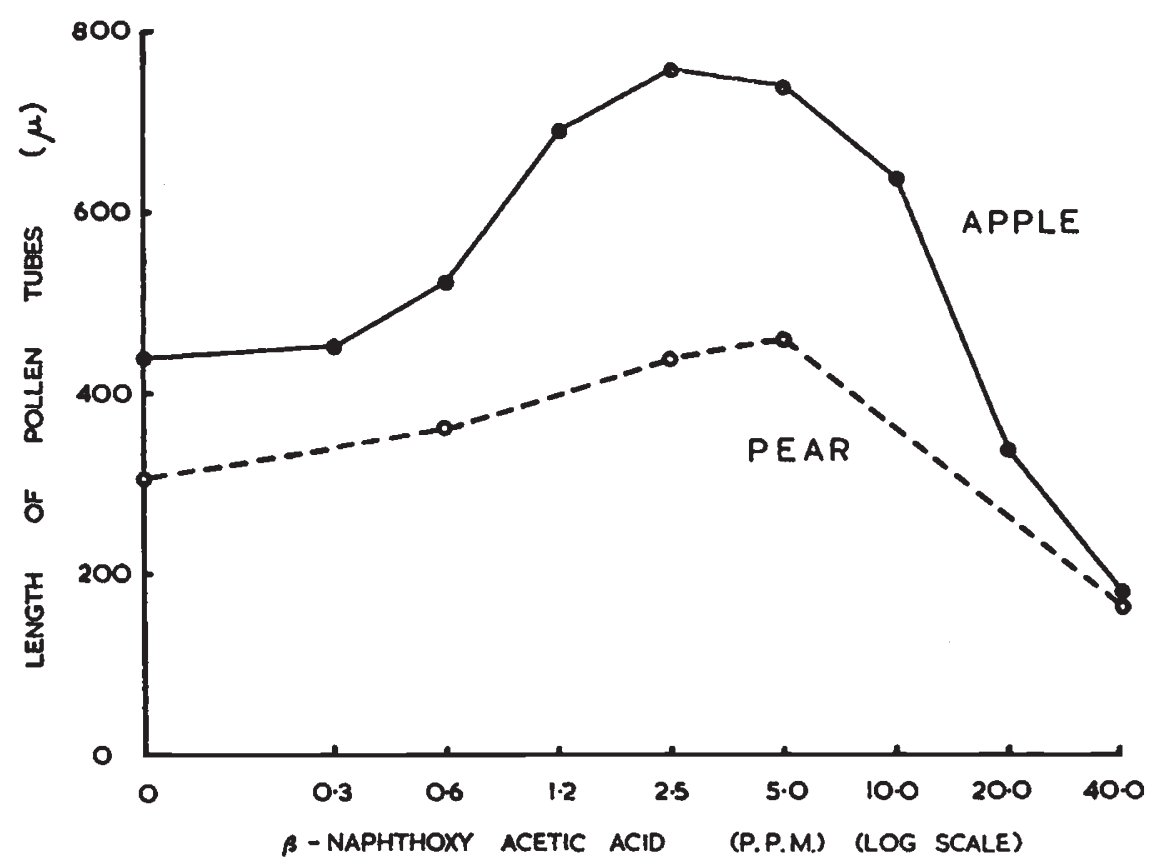

FIG. 1,-Effect of various concentrations of $\beta$-naphthoxy acetic acid on amount of tube growth of Cox apple and Fertility pear pollen. Pollen germinated on cellophane on 15 per cent. sucrose and hormone. Mounted in 0.08 per cent. cotton blue in lacto phenol after growth for 15 hours at $c a .18^{\circ} \mathrm{C}$. and constant humidity.

that in crosses the hormone is applied to the base of the style at a concentration of 40 p.p.m. At this concentration the pollen germination is inhibited (table 2) and the tube growth is slow and abnormal ; many tubes had swollen ends or had burst.

Although the pear pollen tubes grew more slowly than the apple a similar stimulation was induced at the same optimal concentrations.

When growing in pear styles, apple pollen grew more slowly than pear pollen. The application of hormone stimulated the growth of the apple pollen (fig. 2), but it did not seem to affect the growth rate of the pear pollen. This was in general agreement with the results of Modlibowska (1945).

No differences were observed in the growth rate of pollen from 
diploid apple and that from the tetraploid when they were growing in pear styles. In all cases the growth of the apple pollen tubes, although slow, appeared normal.

Fertilisation occurred from five to seven days after pollination in the compatible pear-pear crosses. In the successful pear-apple crosses the pollen tubes did not reach the embryo-sac until ten to twelve days after pollination. Where no hormone was applied no pollen tubes had reached the embryo-sac fourteen days after pollination (fig. 2).

Fertilisation studies on the variety Beurré d'Amanlis, which failed to set any seeds, indicated that after hormone treatment the apple pollen tubes reached the embryo-sac at approximately the same time as in Fertility, ten to twelve days after pollination, thus indicating

TABLE 2

Effect of various concentrations of $\beta$-naphthoxyacetic acid on germination of Cox apple and Fertility pear pollen (cf. fig. I)

\begin{tabular}{|c|c|c|c|c|}
\hline \multirow{2}{*}{$\begin{array}{c}\text { Concentration } \\
\text { of } \beta \text {-naphthoxy } \\
\text { acetic acid }\end{array}$} & \multicolumn{2}{|c|}{ Apple } & \multicolumn{2}{|c|}{ Pear } \\
\hline & $\begin{array}{c}\text { Total } \\
\text { pollen grains }\end{array}$ & $\begin{array}{l}\text { Per cent. } \\
\text { germination }\end{array}$ & $\begin{array}{c}\text { Total } \\
\text { pollen grains }\end{array}$ & $\begin{array}{l}\text { Per cent. } \\
\text { germination }\end{array}$ \\
\hline $\begin{array}{c}\text { o } \\
2.5 \text { p.p.m. } \\
5.0 \text { p.p.m. } \\
4^{0} \text { p.p.m. }\end{array}$ & $\begin{array}{l}597 \\
604 \\
606 \\
606\end{array}$ & $\begin{array}{l}78 \cdot 4 \\
83 \cdot 8 \\
8 r \cdot 8 \\
42 \cdot 7\end{array}$ & $\begin{array}{l}546 \\
572 \\
602 \\
674\end{array}$ & $\begin{array}{l}84 \cdot 6 \\
89 \cdot 7 \\
79 \cdot 7 \\
47 \cdot 6\end{array}$ \\
\hline
\end{tabular}

that the reason for the failure of hybridisation, in Beurré d'Amanlis at least, was not failure of fertilisation. Although Beurré d'Amanlis is a triploid, pollen from compatible diploid pears gives good fruit set and some seed (Crane and Lewis, r942), so here the hormone, although assisting fertilisation, failed to prevent abscission and the young hybrids were lost.

In the pear-cherry and pear-plum pollinations no pollen tubes had reached the embryo-sac by fourteen days after pollination.

\section{CHARACTERS OF THE HYBRIDS}

Chromosome number.-Proof of the hybrid nature of the seed was given by cytological examination of the seedlings. Six seedlings from the cross diploid pear $\times$ tetraploid apple were all found to be triploid $\left(2 n=5^{\mathrm{I}}\right)$. Six seedlings from the cross diploid pear $\times$ diploid apple were all diploid $(2 n=34)$.

Seed germination and seedling growth.-Both the diploid and the triploid seed from the pear-apple crosses had 82 per cent. germination as compared with $9^{8}$ per cent. germination for the seed from the pearpear cross. As with the seedlings grown by Crane and Marks (1952), the subsequent development was, however, unusual. Within a month some of the seedlings were wilting and lacking in vigour. The triploid seedlings were the most affected and after four months 85 per 
cent. of the triploid seedlings and 39 per cent. of the diploid seedlings had died.

The seedlings appeared to have a defective root system and grafts were made to apple and pear stocks by Mr A. G. Brown. Preliminary
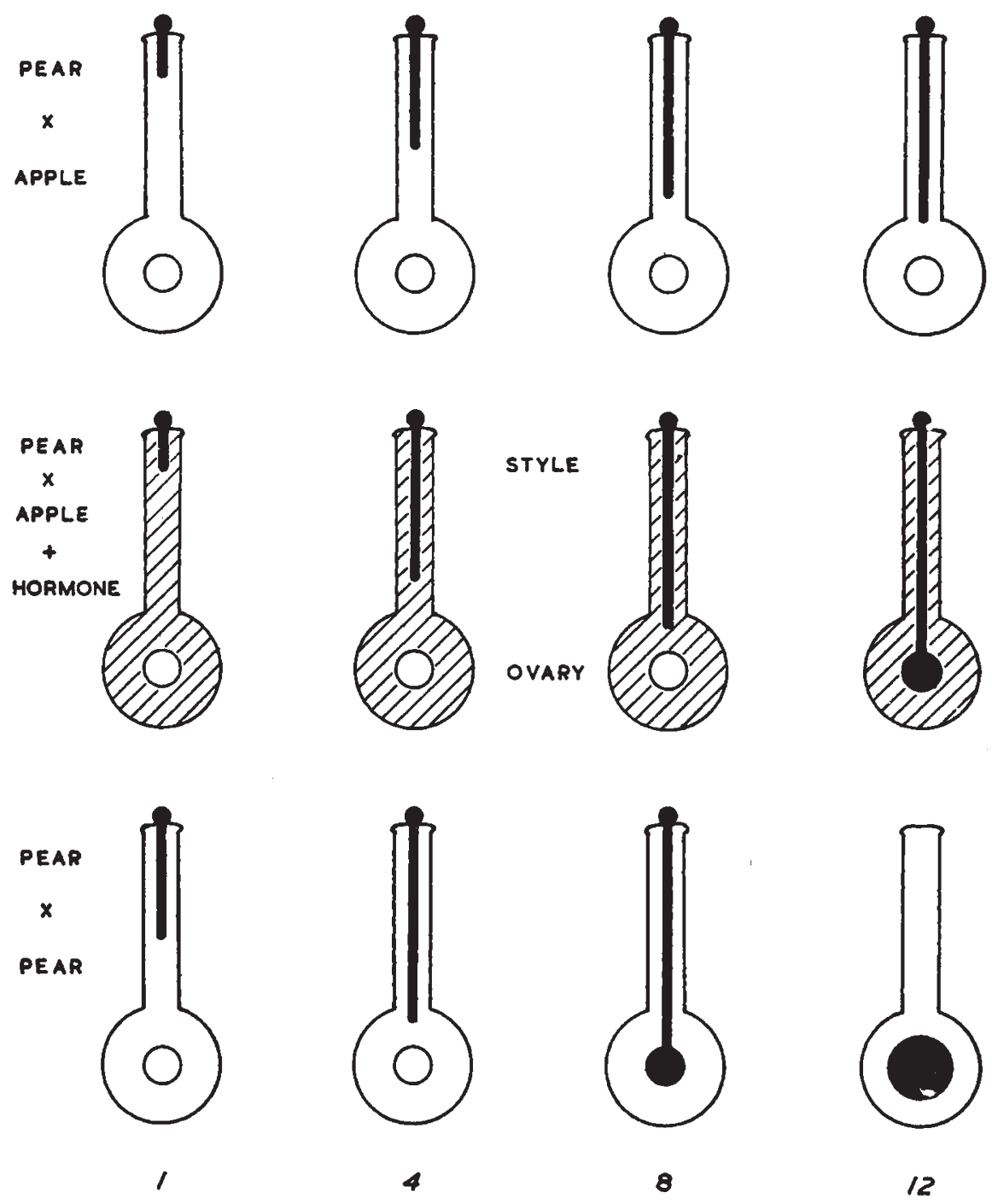

\section{DAYS AFTER POLLINATION}

FIG. 2.-Diagram of pollen tube growth and fertilisation in pear $\times$ pear and pear $\times$ apple crosses.

results suggest that when grafted they grow much better. More success has been achieved with apple stocks but some grafts are growing well on pear stocks.

External characters.-As the hybrid seedlings were only observed during their first season it was not possible to define their genetic 
characters with certainty. The hybrids developed intermediate characters and were distinct from either apple or pear seedlings. Crane and Lewis (1949) have listed various genetic characters for pear varieties and Lewis and Crane (1938) some for apple varieties. Table 3 is an attempted classification of the $F_{1}$ pear-apple hybrids using these characters. The hairiness of the summer shoots and the serrate leaf margins resembled the apple parents and the dull green leaf colour was like that of apple seedlings. In the cross involving Comice, however, the pale red colour of the stem and the relatively

TABLE 3

Characters of pear-apple hybrids and parent varieties

\begin{tabular}{|c|c|c|c|c|}
\hline $\begin{array}{l}\text { Variety or } \\
\text { hybrid }\end{array}$ & $\begin{array}{l}\text { Summer } \\
\text { shoots }\end{array}$ & $\begin{array}{c}\text { Leaf } \\
\text { margins }\end{array}$ & $\begin{array}{l}\text { Glands on } \\
\text { main leaf } \\
\text { midrib }\end{array}$ & $\begin{array}{l}\text { Leaf } \\
\text { surface }\end{array}$ \\
\hline $\begin{array}{l}\text { PeAR } \\
\text { Fertility }(2 x) \\
\text { Comice }(2 x)\end{array}$ & $\begin{array}{c}\text { Red, } \\
\text { sub-glabrous } \\
\text { Pale red, } \\
\text { sub-glabrous }\end{array}$ & $\begin{array}{l}\text { Serrate- } \\
\text { crenate } \\
\text { Crenate }\end{array}$ & $\begin{array}{c}\text { Red } \\
\text { Few, red }\end{array}$ & $\begin{array}{c}\text { Shiny } \\
\text { " }\end{array}$ \\
\hline $\begin{array}{l}\text { APPLE } \\
\quad \text { Cox }(2 x) \\
\text { I6-36 AT }\left(4^{x}\right):\end{array}$ & Red, hairy & Serrate & Green & Dull \\
\hline $\begin{array}{l}\text { Pear-Apple } \mathbf{F}_{1} \\
\text { Fertility } \times \text { Cox }(2 x) \\
\text { Fertility } \times \text { r6-36 AT }(3 x) \\
\text { Comice } \times \text { I6-36 AT }(3 x) .\end{array}$ & $\begin{array}{c}\text { Red, hairy } \\
\text { Pale red, hairy }\end{array}$ & $\begin{array}{c}\text { Serrate } \\
,,\end{array}$ & $\begin{array}{c}\text { Red } \\
\text { Few, red }\end{array}$ & $\begin{array}{l}\text { Dull } \\
, "\end{array}$ \\
\hline
\end{tabular}

few glands on the leaf midrib resembled the pear parent. Many of the hybrid seedlings had occasional lobed leaves, a character which is commonly observed in pear seedlings, but rarely in apple seedlings.

\section{DISCUSSION}

In considering the reasons for the success of the hormone in assisting fertilisation two effects have been demonstrated; it stimulates pollen tube growth and induces parthenocarpic fruit set.

With hormone, pear-apple fertilisation is delayed by comparison with pear-pear fertilisation and without hormone it does not occur within fourteen days, if at all. The importance of this delayed fertilisation can be best assessed by a consideration of the mechanism of fruit drop in the pome fruits.

Luckwill (1952) emphasises the relationship between development of the endosperm, the auxin content of the developing seed, and the time of fruit drop in apples. The first two to three weeks after petal fall are characterised by the virtual absence of auxin in the seed. During this period the endosperm is non-cellular and developing 
rapidly. It becomes collular after about three weeks and at the same time auxin first appears in the seed. This coincides with the end of the "first drop". Once the endosperm becomes cellular it begins to produce a secondary endosperm and in doing so much of the primary endosperm is digested. Thus there is an initial decrease in the amount of endosperm followed by a rapid rise. This period of decrease is correlated with a low auxin content and coincides with the period of the "June drop".

Thus we can see that the fate of a late fertilised hybrid depends very largely on the auxin content of the ovule, which in turn is related to its stage of growth. It is very unlikely that the late fertilised pearapple hybrid will be capable of producing natural auxins in time to prevent abscission. In naturally parthenocarpic varieties, however, the supply of auxin is less dependent on the development of the seed and can be supplemented by the application of hormone. Hence the success of the technique employed here is dependent, first on the stimulation of the pollen tube growth which allows fertilisation to take place, and secondly on a supply of hormone which prevents the formation of the abscission layer.

The reason for the failure of the pear-apple cross with most varieties and the complete failure of the reciprocal apple-pear cross is probably the inability of these varieties to react to the hormone in preventing the formation of the abscission layer, which in turn is related to their genetically lower auxin production. This suggests that in naturally parthenocarpic fruit an alternative site of hormone production is more strongly developed. Incidentally, intergeneric hybrids in the Pomoideæ have been most easily made in the past with varieties which are naturally parthenocarpic.

Osborne and Wain (I95I) have shown that parthenocarpic fruit set is possible on apples. But a different hormone from the one successful on pears is necessary. Failure of fertilisation may contribute to the lack of success in apples. The slower growing pear pollen tubes (fig. I) have a longer path to travel (apple styles ro mm., pear styles $6 \mathrm{~mm}$.) and the apple styles degenerate six to eight days after they become receptive.

Dr W. O. James tells me that the growth of roots by barley seedlings on White's culture solution is much improved by the addition of an extract from the endosperm. Thus the endosperm seems to produce a substance which is necessary for normal root growth and in this way the later beginning of the hybrid seeds is probably related to the poor root growth of the young seedlings.

The effect of the hormone in inducing parthenocarpy is much more specific than its effect on stimulation of pollen tube growth. Hence further hybridisation should be based on the selection of varieties and hormone treatments which, through parthenocarpic fruit development, will provide a medium for the late developing hybrid seeds and prevent loss through abscission. 


\section{SUMMARY}

I. Hybridisation and parthenocarpy were produced by applying $\beta$-naphthoxyacetic acid to the base of the style of the pear at the same time as the apple pollen was applied to the stigma.

2. The hormone stimulated the growth of the apple pollen tubes and thus allowed fertilisation to occur, but this was later than pearpear fertilisation.

3. The success of the cross also depends on the effect of the hormone in inducing parthenocarpy and preventing the loss of the late developing hybrids.

4. The growth of the pear-apple seedlings was abnormal but four months after germination 37 per cent. still survived. The seedlings were otherwise intermediate in character between pears and apples.

Acknowledgment.-This work was done while at the John Innes Horticultural Institution, Bayfordbury, Herts. on a Studentship from the Commonwealth Scientific and Industrial Research Organisation, Australia. I wish to express my thanks to Dr G. D. Darlington and Mr M. B. Crane for facilities, helpful advice and criticism.

\section{REFERENCES}

ADdicotT, F. T. 1943. Pollen germination and pollen tube growth, as influenced by pure growth substances. Plant Physiol., 18, 270-279.

AVERY, G. S., AND JOHNSON, E. B. 1947. Hormones and Horticulture, McGraw Hill, New York.

CRANE, M. B., AND LEWIS, D. 1942. Genetical studies in pears. III. Incompatibility and sterility. F. Genet., 43, $31-43$.

CRANE, M. B., AND LEWIS, D. I 949 . Genetical studies in pears. V. Vegetive and fruit characters. Heredity, 3, 85-97.

CRANe, M. B., AND marks, G. E. I952. Pear-apple hybrids. Nature, 170, 1017.

DARLINGTON, C. D., AND LA COUR, L. F. 1947. The Handling of Chromosomes. Allen and Unwin, London.

EAST, е. м. I923. Genetical aspects of self and cross-sterility. Amer. F. Bot., ro, $468-473$.

EMSWELLER, S. I., AND STUART, N. W. 1948. Use of growth regulating substances to overcome incompatibilities in Lilium. Proc. Amer. Soc. Hort. Sci., 5I, 58I-589.

LEWIS, D. I948. Structure of the incompatibility gene. I. Spontaneous mutation rate. Heredity, 2, 219-236.

LEWIS, D., AND CRANE, M. B. 1938. Genetical studies in apples. II. $\mathcal{F}$. Genet., 37, I I 9-1 28.

LUCKWILL, L. c. I952. The mechanism of fruit drop in pome fruits and its control by synthetic growth-substances. Rep. 13th int. Hort. Congr. Lond., pp. 223-229.

marks, G. E. 1953. Genetical studies in pears. VI. Giant bud sports. F. hort. Sci., $28,141-144$.

Modisowska, I. 1945. Pollen tube growth and embryo-sac development in apples and pears. F. Pomol., 21, 57-89.

OSBORNE, D. J., AND WAIN, R. L. I95I. Studies on plant growth-regulating substances. III. The production of parthenocarpic pomaceous fruits by chemical treatment. F. hort. Sci., 26, 31 7-327.

SMITH, P. F. 1942. Studies of the growth of pollen with respect to temperature, auxins, colchicine and vitamin B1. Amer. 7. Bot., 29, 56-66.

WANSCHER, J. H. 1939. Contributions to the cytology and life history of apples and pears. Roy. Veter. and Agric. Coll. Yearbook, Copenhagen, pp. 21-70.

zimmermanN, P. W., ANd hitchCock, A. E. 1948. Plant hormones. Annu. Rev. Biochem., $17,601-626$. 